\title{
Developing Islamic Religious Education Curriculum in an Inclusive School Using International Curriculum (a Study at Madania Bogor Senior High School)
}

\author{
$1^{\text {st }}$ Isnawati $^{1}, 2^{\text {nd }}$ Muhammad Yusuf ${ }^{2}, 3^{\text {rd }}$ Arif Zamhari $^{3,} 4^{\text {th }}$ Nuryasin $^{4}$ \\ \{isnawati17@mhsuinjkt.ac.id ${ }^{1}$, muhammad_yusuf17@mhs.uinjkt.ac.id ${ }^{2}$, arif.zamhari@uinjkt.ac.id ${ }^{3}$, \\ nuryasin@uinjkt.ac.id \} \\ UIN Syarif Hidayatullah Jakarta ${ }^{1,2,3,4}$
}

\begin{abstract}
This study described how the Islamic Religious Education curriculum was developed in Madania Senior High School as an inclusive educational institution using the Cambridge International curriculum. This research was a qualitative study employing field research, observations, and interviews as data collection methods. The primary data sources were the Islamic Religious Education Syllabus, the results of observations, and interviews. Furthermore, the official education authority's curriculum syllabus, the Islamic school, and the Cambridge Curriculum Syllabus as well as other authoritative literature were utilized as the secondary data. The data collected were then processed and analyzed descriptively. This study found that five processes were carried out to improve the Islamic Religious Education curriculum at Madania, namely planning, developing, reviewing, validating, and evaluating. The Islamic Religious Education curriculum settled was humanistic and tolerant. The religious content was in line with moderate Islamic teaching which upheld tolerant and inclusive attitudes following Madania's vision and mission.
\end{abstract}

Keywords: Cambridge International curriculum, curriculum development, Islamic religious education (PAI).

\section{Introduction}

In Indonesia, education continued to develop with the increasing variety of formal educational institutions to choose from. People did not only recognize two school categories (public and private schools), but they had also been familiar with International educational platforms in which the implementation had been formally regulated [11].

An International school was a formal educational platform using not only local/national curricula but also other countries' syllabuses in their educational system [26]. As stated in the Regulation of the General Director of Basic Education of the Ministry of Education and Culture Number 105/C/KEP/LN/2014, several foreign curricula commonly used in Indonesia were International Baccalaureate (IB), Cambridge International Examinations (CIE), Western Association School Colleges (WASC), and others.

Of the several International curricula above, the Cambridge International curriculum was the most common and widely adopted curriculum by Indonesian International schools [8]. Since 2012, exams using this syllabus had increased by 15\%. 28,000 assessments were administered by several Indonesian educational institutions employing this program. 
Cambridge International curriculum offered an International program with good qualifications and examinations in more than 160 countries at 10,000 schools, including Indonesian schools [31]. The fact brought this study for researching a school adopting this curriculum.

Since the issuance of the regulation of the Ministry of Education and Culture Number 31 of 2014 concerning cooperation in the education implementation and management by overseas educational associations with Indonesian educational institutions, International schools should change their status to be Cooperation Program Units (SPK) to continue their platforms. The Cooperation Education Unit (SPK) was organized or managed based on collaboration between an accredited or recognized Foreign Education Foundation (LPA) and the Indonesian Education Institution (LPI) on a formal basis grounded in statutory provisions.

Recently, Indonesia occupied the top position in Southeast Asia with the largest number of International schools and placed 10th position in the global area. Haifa Segeir, Head of the Indonesian SPK School Association [12] stated that the trend of parents' interest in sending their children to International schools sharply increased from time to time. Based on his analysis, this fact was related to macroeconomic conditions that greatly affected people's purchasing power and the desire to bring their children for learning in higher quality institutions.

Schools with SPK status were required to take both national and International standard exams (article 5). The adopted curriculum had to include three main lessons in their syllabus, namely religious education, civic, and Indonesian Language learnings (Article 11 Paragraph 3 ). Considering the regulation, religious education was one of the required subjects that should be covered in the curriculum.

This study analyzed several reasons for choosing Islamic education as a compulsory subject in International schools. First, the main great personality could be only shaped through religious education [28]. Several studies also identified that religious education could be a provision strengthening individuals' personalities for competing in the International landscape [30], [21], [14].

Second, based on the Indonesian culture in the Preamble to the 1945 Constitution, the learning mandate emphasized the primary dimensions for being mastered and internalized by Indonesian students through religious edification. As a country using Pancasila as a foundation, Indonesia highlighted the students to uphold the essence of divinity reflected in the precepts of the first part of Pancasila, which acknowledged the existence of God Almighty. This noble national identity directly indicated the importance of strengthening the spiritual dimension through the obligation for providing religious subjects at schools.

The mandated religious education should be taught according to the student's beliefs. Since Islam was an official religion and mostly followed by Indonesian people [3], [29], [37], it could be predicted that Muslim students were easily found in most of the International schools, and therefore Islamic education subjects should be provided there.

Another reason for supporting the existence and urgency of Islamic religious education subjects in International schools was stated in Law no. 20 of 2003 concerning the National Education System, especially in chapter five article twelve (12) in paragraph 1 part (a) which stipulated that every student received their right to acquire religious education in the school. However, based on the preliminary research, religion lessons were not given in some International schools. This happened because some stakeholders viewed religion as a personal matter. However, because the schools were placed in Indonesia, they inevitably had to follow the policies and education system for providing religious subjects in the main curriculum.

Besides, another reason for doing this study was the fact that some International schools did not provide any textbooks for the learning process so that the teachers should design the 
materials. If Islamic education received less attention in the formal schools, it was feared that a dichotomy between science and religion appeared. The students were not only expected to be intelligent by mastering general discipline well, but also had strong faith, and good religious spirituality [22]. If the curriculum was designed systematically and comprehensively and integrated into the students' development and learning needs to prepare them for facing a real-life, the learning results or outputs would realize the students' expectations [10].

The data obtained through interviewing Islamic education teachers from two different schools indicated that each International school had different foundations in designing the curriculum for subjects that were not included in the adopted International curriculum scope, including religious subjects. This fact also took this study for researching the curriculum development topic to investigate the impact deeply.

Madania senior high school was chosen as the research object since the institution was categorized as a Cooperation Education Unit. This study focused to gain the data on the high school level for obtaining more comprehensive data and information. Madania senior high school integrated the National and Cambridge International curriculum. Through the national curriculum, students strengthened their Indonesian traditional roots. The enrichment by the Cambridge syllabus aimed to empower the students for competing globally and develop them for being qualified learners [20].

Based on the mentioned reasons, this study researched on how the process of developing the Islamic Religious Education (PAI) curriculum at Madania senior high school as an inclusive educational platform using the Cambridge International curriculum.

Theoretically, this study is useful for the contribution of knowledge, especially in the field of the development of Islamic religious education curriculum in the international school. For practical use, this review can be used as a best practice for Islamic religious education institutions in instilling the values of humanism and inclusifism for student also inspiration and recommendation for the government in making policies related to the development of Islamic religious education curriculum.

\section{Literature Review}

Throughout the search for the relevant literature, the academic discourse on the development of Islamic religious education curriculum [17, [32], [46], [47]. Very few researchers research international schools, some of the research most often discusses how to develop curriculum in national schools. The difference between my research and previous research is that this research focuses on how inclusive educational institutions use an international curriculum to view the urgency and develop their Islamic Religious Education curriculum. Ada satu kajian yang menarik yang dilakukan oleh Tony Luxon dan Moiro Peelo pada tahun 2009 yang berjudul Internationalisation : Its Implications For Curriculum Design and Course Development In UK Higher Education [19].

\section{Methodology}

This study was qualitative research analyzing the curriculum development in Madania senior high school as an inclusive educational platform employing the Cambridge International curriculum. This school was chosen since Madania accommodated six religions, namely Islam, Catholicism, Protestantism, Hinduism, Buddhism, and Jehovah's Witnesses. 
This factor allowed this study to acquire a comprehensive picture of how the Islamic education curriculum was developed in an inclusive and tolerant educational institution.

The research data were divided into two types, namely primary, and secondary data sources [23]. The primary data sources were obtained directly from the main research bases [7], while secondary data (supporting) sources were gained from the previous studies and other relevant documents [35].

This research was a qualitative study implementing field research data collection methods by conducting direct research into the field and employing direct observations and interviews with related parties. The primary data sources used were the Islamic Religious Education Learning Syllabus (PAI) at Madania senior high school, the results of observations, interviews, and other findings during the study. Furthermore, the secondary data sources were the Education Curriculum Syllabus, Islamic education (Madrasah), and Cambridge International Curriculum Syllabus, as well as other authoritative literature investigating the development of Islamic Religious Education (PAI) curriculum. The data collected were then processed and analyzed using descriptive analysis.

\section{Result and Discussion}

\subsection{Curriculum development}

Curriculum development was referred to as a plan carried out to guide students towards expected changes and assess the improvement impact on the learners [45]. Curriculum development was applied based on realities in the field. Development activities should be focused on the pupils' needs and abilities for the reason that each student had different skills and potentials. Moreover, learning objectives were difficult to achieve if the curriculum development process was not implemented based on the learners' condition [2].

Several approaches were recommended by experts in developing a curriculum, such as top-down and grass-root approaches [34], [35]. The top-down or administrative approach suggested by Robert S. Zais was implemented by instructing from the top-level [48]. Initiatives and directions regarding curriculum development emerged from education policymakers such as the General Director or the head of regional office, and other leads. Schools only needed to implement the curriculum. This kind of approach was also known as the line staff model and was usually implemented by some countries having a centralized education system [1].

Contrarily, a grass-roots approach focused on developing a curriculum with teachers' initiatives as the real implementers in the field, and then the idea was taken to the higher-level system [15]. Therefore, this approach was called bottom-up curriculum development. Usually, this approach was employed in the curriculum improvement stage. However, for some cases, this approach was utilized to develop a completely new curriculum (curriculum construction) [38].

\subsection{Cambridge International curriculum}

The Cambridge International curriculum was one of the most widely used International curricula by Indonesian schools. In July 2021, 219 schools from various cities and provinces in Indonesia employed this curriculum [5]. The Cambridge International curriculum was 
adopted from a leading university in the United Kingdom (UK), Cambridge University. Cambridge International Examination (CIE) was part of The Cambridge Assessment Group which was an organization under the auspices of Cambridge University. The focus of this curriculum was improving the students' understanding, knowledge, and skills through their experiences. The learning process was the most significant aspect of this program [4]. This curriculum had four levels, namely: Cambridge Primary Program for students aged 5-11 years, Cambridge Secondary 1 (Lower Secondary) Program for 11-14 years old students, Cambridge Secondary 2 (Upper Secondary) Program for 14-16 years old pupils, and Cambridge Upper Secondary/Advance Program for 16-19 years old learners [4].

Based on the interview with Alfi Afifah, several reasons could be mentioned for the wide use of Cambridge International curriculum, namely the English language used for instructions, International outlook, comprehensive subjects, up-to-date themes, and well recognition [42].

\subsection{Madania Senior High School}

Madania senior high school was an educational institution under the Indonesian Madania Education Foundation (YPMI). This foundation was established by Cak Nur, Achmad Fuadi, Komaruddin Hidayat, and Khoirul Roziqin in 1995 (Nafis, 2014: 185). The name "Madania" came from the Arabic "madaniah", the root word of Medina, which meant civilization.

In 1996, YPMI built the Madania Schools. Madania was an Indonesian school that respected different religions and thought, and considered students' learning needs and abilities in developing the curriculum. Madania Schools provided learning experiences using an Indonesian wisdom atmosphere respecting spirituality, tradition, virtue, art, culture, and the nation's history. These schools developed an International standard curriculum supported by qualified human resources, learning programs, and facilities [16].

Madania Schools had a vision of "A True Indonesian School for the Leaders". Its mission was "Reviving consciousness of God, actualizing world-class standards, living with the noble character, and respecting Indonesian values". These schools had several levels ranging from kindergarten, elementary, and high schools. Madania Schools had applied the Cambridge International curriculum at the senior high school level since 2010 at the Cambridge Secondary 2 and Advanced levels [9].

The school environment was very dynamic, supportive, and challenging, supporting the students to grow properly for being outstanding generations. Various programs, such as; prohibiting smoking and using harmful drugs, giving sex and puberty education, building teamwork, and personal development activities were presented in well-planned programs. The moving class system was applied from the seventh grade. Foreign language learnings like Arabic, German, Mandarin, and Japanese were offered to the lower class, and then the students chose their preferred language to deeply study. After graduating from Madania Schools, students were expected to have National and Cambridge International Examination certificates, and a single foreign language recognition document.

In Madania, students and teachers learned to comprehend and appreciate the diversity of religion, ethnicity, and culture, as God's designed phenomenon which had become a social reality that could not be eliminated. This inclusive attitude was not only applied in the religious aspect. Each class had also at least two special needs students so that they were welleducated to be empathetic and easy to help others [13]. Madania school was located in the Kahuripan Complex, Kemang, Bogor. Its uniqueness brought the West Java Provincial Government to set this school as a reference and mentor for other schools, especially in the 
aspect of inclusive education accepting special needs students and tolerant edification in addressing different religions [13].

\subsection{Development of Islamic Religious Education curriculum (PAI) at Madania Senior High School}

In this part, the curriculum development processes at Madania senior high school were described, starting from planning, developing, reviewing, validating, until evaluating. Furthermore, a comparative analysis of the Islamic education, Cambridge, and Madania syllabus was completed to know the difference between the developed syllabus by the MCDQA Team (Madania Curriculum Development and Quality Assurance) and the National Education curriculum syllabus.

a. Islamic Education Curriculum Development Process at Madania Senior High School

Beverly Nichols in his book entitled "Managing Curriculum and Assessment: A Practitioner's Guide" explained three central stages in the Curriculum Management Model, namely needs analysis, planning, and design, and implementation [27]. In the process, Nichols provided a pivotal point in the students' needs analysis and put it as the first step to take. A needs analysis was essential because the curriculum developers could find the right focal point based on the students' necessities. A needs analysis was firstly taken to maximize the benefits of curriculum review, development, and evaluation [27].

Based on the research results, in general, four significant stages were applied in the curriculum development process. The stages included the planning step, the development process, review and validation, and evaluation.

1) Planning Stage

In the planning stage, several points were determined by the curriculum development team, MCDQA (Madania Curriculum Development and Quality Assurance), such as the approach, sources, and some methods used for analyzing students' needs. Based on the interview and observation results, a humanistic, technological, and top-down approach was applied. The humanistic approach was echoed by Muhaimin in several books stating that this method put forward the concept of humanizing humans, in which student-centered was dominantly implemented [24], [25].

In developing the curriculum, parents' and students' inputs and suggestions were highly considered. This argument was delivered by Alfi Afifah as the chairman, Adam Hermawan as the MCDQA team, and Ninik Ni'matur Rahmaniyah as the coordinator of the religious subject teacher. This process was covered in the planning and data collection stages when constructing the curriculum as in the flow map at the beginning of the discussion.

Ninik added that at the beginning of every semester, the KWL (Know-Want to KnowLearned) method popularized by Ogle [6] was applied. In practice, the students were allowed to write down the themes/materials/discussions they would know in their language. Then, Ninik prepared a sheet of wide paper and the students glued their writings on it. The students' opinions were then analyzed to recognize what exactly they want to know and need.

Besides the humanistic approach, the technological approach was also employed in developing the Islamic education curriculum at Madania senior high school. This approach was applied both in the theory and application stages. Based on the observation and interview results, the application of the technological approach was written in the designed syllabus. This fact was mentioned by Mr. Ahmad Nurhidayat and Mr. Abdullah, two Islamic education teachers who played as the research participants [39], [41]. 
The respondents also described several materials illustrating the implementation of this approach, including the theme "da'wah" in class XII. In this material, the students did not only learn the provided material but were also asked to make interactive videos in groups. This method was also implemented in teaching other themes.

The top-down approach was also applied. Theoretically, this approach was implemented by getting instructions from the top level such as education policymakers as the basis for developing the curriculum. Therefore, this approach was often referred to as the line staff model [33] [34]. In Madania, this approach was intended to develop a curriculum structured from the senior to junior and elementary schools. This aimed to make developers easily compile and link themes, so the materials in the elementary school were prerequisite materials in junior high school and so on [42]. This study analyzed the more appropriate term to name the approach used which was the descending method since they developed the materials from the top to bottom level [36]. This argument was referred to as the reason for selecting this method that had no political agenda, while the top-down approach was known as an approach with politically hierarchical from the highest education policyholders to the lower level.

Five main sources were used to develop the curriculum at Madania senior high school, namely National Education Curriculum (reference and format), Islamic Boarding School Curriculum (standardization), Cambridge International Curriculum (approach), Developing Country Curriculum (comparison), and MLP (Madania Learning Profile). These sources were collected by the Curriculum Team from MCDQA. The subject teachers then analyzed the themes and materials. After collecting the sources, students' needs analysis was compiled. In this case, several methods used by the Madania senior high school curriculum development team were focus group discussions (FGD), student interviews, KWL (Know-Want to KnowLearned) method, and asking parents for input.

2) Development Stage

The curriculum development process was carried out by the MCDQA (Madania Curriculum Development and Quality Assurance) Team consisting of Alfi Afifah, Adam Hermawan, an Islamic education teacher coordinator, and some Islamic education teachers. The steps were breaking down basic competencies (KD), mapping themes, compiling and adjusting learning indicators with the Madania Learner Profile (MLP), and designing the syllabus.

Breaking down the basic competencies was done for the reason that not all the themes in the National Education Curriculum Syllabus were covered by Madania senior high school. After that, a theme mapping was carried out. Some themes were completely removed, while some were replaced with other more relevant topics. The deletion and replacement of the issues were adjusted to the students' needs based on the observation results and analyses conducted by the MCDQA Team as curriculum developers.

In the interview session, Adam Hermawan explained that three additional themes were included in the Islamic education syllabuses which were not covered in the National Education syllabus. The themes were anti-corruption, social ethics in social media, and an inclusive attitude education. Anti-corruption education was given considering the high number of corruption cases in Indonesia, so the curriculum developers considered this topic was essential to learn. This theme was emphasized in the honesty chapter. It was given as a preventive effort for the students to have honest personalities and high integrity so that they did not corrupt [40].

The theme of social media ethics was offered as an effort to guide students for using social media properly, giving kind and polite words in communicating, and avoiding the spread of hoaxes and SARA (ethnicity, religion, race, and between groups), pornography, and 
violent action in social media. Furthermore, the inclusive theme was emphasized because this was a core value brought by Madania School as an inclusive educational institution that upheld the value of tolerance and accommodated six religions. After mapping the themes, the next step was arranging indicators for contained values in the Madania Learner Profile (MLP) to enrich the learning objectives.

3) Review, Validation, and Evaluation

The developed Islamic education syllabus was reviewed and validated before being implemented. The review was carried out by the Islamic education subject teachers. In the interview session, Alfi Afifah explicated that the curriculum developer inputted and designed the new Islamic Religious Education (PAI) syllabus. The review was completed to ensure that the developed syllabus was following the classroom conditions since the teacher was the spearhead in the education and learning process. No matter how well the curriculum was designed, if it was not implemented properly by the teacher, the curriculum did not mean anything. Therefore, before applying the syllabus, the developed curriculum should be reviewed by the teacher [42].

After the curriculum has been reviewed, the next step was validation. Validation was the final stage of the curriculum development process. The school director, principal, head of MCDQA, and Islamic education subject Coordinator (PAI) Madania School were involved in this step. After being applied for two semesters, the syllabus was re-evaluated and adjusted to the student's development and needs. However, based on the interview with Adam Hermawan as a member of the Curriculum Development Team from MCDQA, no written criteria or standard was explicitly mentioned regarding how the developed curriculum should be.

b. Comparative and Differentiation Analysis of Madania Senior High School Curriculum

In general, the Madania curriculum should meet several standards which would later differentiate it from other curricula. After the development process, several differences of the Madania senior high school curriculum from the National Education Curriculum, namely:

1) Emphasis on Madania Learner Profile (MLP) values on the indicators of Islamic education syllabus

The contained values in the MLP brought the Madania curriculum syllabus to be different from another curriculum. The MLP values were explicitly mentioned in the syllabus table for each indicator. The syllabus clearly showed that each theme highlighted one or more MLP values that aimed to achieve Madania's vision.

2) The addition of three major themes, namely anti-corruption, social ethics in social media, and inclusiveness education

The inclusion of three major themes was aimed to support students for being future leaders as in the Madania School's vision and mission. The technique for teaching these topics was specifically for certain classes, especially in the higher secondary levels. Some issues were specially scheduled and separated from the classroom learning process. The material was called "prophetic leadership". Religion teachers as the learning designers had already covered those three themes integrated into the PBM.

3) Enrichment of Indicators and adjustments to the basic competencies of the 21 st century

Four skills had to be possessed by 21 st-century students, commonly known as $4 \mathrm{Cs}$ consisting of critical thinking and problem solving, creativity, communication skills, and collaboration [18]. These four skills had been encompassed in the learning outcomes indicators in the Islamic Education learning syllabus as a result of the curriculum development.

Besides mentioned differentiations, a significant point that characterized and emphasized the Islamic Religious Education curriculum which was then applied in the learning process 
was humanistic and tolerant attitudes. In Madania, the individual relationships among students, teachers, and staff were good. They tolerated other religious followers without losing their respective religious identities. When the students from other religions worshipped, other pupils respected them. In Madania, some places aimed at worship for each religion were provided, intended for Muslims, Christians, Catholics, Hindus, Buddhists, and Jehovah.

Madania students learned about tolerance and inclusivism not only at the theoretical level but also directly in their daily lives. This habit may hardly be found in other educational institutions. 36 teachers worked at Madania senior high school, both full and part-time. Six religious teachers worked to teach Christian, Catholic, Hindu, Buddhist, and Jehovah, while two teachers taught general subjects [44].

This study argued that Madania senior high school could be used as an example of how differences created a beautiful and strong harmony. This school was a forum for how tolerance and inclusivism were implemented.

\section{Conclusion}

The Islamic education syllabus at Madania senior high school was developed by Madania Curriculum Development and Quality Assurance (MCDQA) team by carrying out five processes, namely planning, developing, reviewing, validating, and evaluating. The learning indicators in the developed syllabus were richer since they were designed using the Cambridge International approach and emphasized the Madania Learner Profile (MLP) values. The interesting finding of this study was the use of a descending approach by the curriculum developers for designing the curriculum from the highest to the lower level. This was implemented because the material at the elementary level was a prerequisite for the junior and senior high school materials. Therefore, the curriculum was interconnected from elementary, junior, and high school stages. Additionally, the religious content in the syllabus was in line with moderate Islamic teaching which maintained a tolerant and inclusive attitude following the school's vision, mission, and values.

\section{References}

[1] Almu'tasim, A. "Menakar Model Pengembangan Kurikulum Di Madrasah". At-Tuhfah: Jurnal Studi Keislaman. 7(2). (2018) .1-19.

[2] Al-Tabany, Trianto Ibnu Badar. Mendesain Model Pembelajaran Inovatif, Progresif, dan Konteksual. Jakarta: Prenada Media. (2017).

[3] Anwar, C. "Islam Dan Kebhinekaan Di Indonesia: Peran Agama Dalam Merawat Perbedaan". Zawiyah: Jurnal Pemikiran Islam, 4(2), 1-18. (2018).

[4] Cambridge International Examination from www.cie.org.uk on October 04, 2019

[5] Cambridge Pathway. Accessed from https://www.cambridgeinternational.org on 24 Juli 2021

[6] Carr, Eileen, \& Ogle, Donna "KWL Plus: A Strategy for Comprehension And Summarization". Journal of Reading, 30(7),. (1987). 626-631.

[7] Creswell, Jhon W. Research Design: Qualitative, Quantitative and Mixed Method Approaches. Califonia: Sage Publications. (2017).

[8] Elfrida, D., Santosa, H., \& Soefijanto, T. A. "Pengaruh Kompetensi Guru dan Implementasi Kurikulum Asing Terhadap Kinerja Guru di Sekolah Internasional Jakarta Utara”. Tadbir: Jurnal Studi Manajemen Pendidikan. 4(1), (2020). 53-66. 
[9] Find a Cambridge School accesses from https://www.cambridgeinternational.org om July 24, 2021

[10] Hatim, M. "Kurikulum Pendidikan Agama Islam di Sekolah Umum”. EL-HIKMAH: Jurnal Kajian dan Penelitian Pendidikan Islam, 12(2), (2018). 140-163.

[11] Hendriyani, W., \& Nadya, N. "Mengapa Memilih Sekolah Internasional? (Studi Kasus Pengambilan Keputusan Orangtua Dalam Pemilihan Sekolah Untuk Anak)". INQUIRY: Jurnal Ilmiah Psikologi, 9(1), (2018). 16-31.

[12] Herlinda, W.D. 2017, Juni 4. Sekolah Internasional Wajib Ganti Status Jadi SPK: Bagaimana Standar Pendidikannya? Accessed from http://kabar24.bisnis.com/read /20170604/255/659062/standar-pendidikannya

[13] Hidayat, Komaruddin. Sekolah Inklusif Madania. Koran Sindo 5 April 2019

[14] Hidayat, R., Sarbini, M., \& Maulida, A. "Peran Guru Pendidikan Agama Islam dan Budi Pekerti dalam Membentuk Kepribadian Siswa SMK Al-Bana Cilebut Bogor”. Prosa PAI: Prosiding Al Hidayah Pendidikan Agama Islam, 1(1B), (2018). 146-157.

[15] Huda, Nurul. 2019. "Pendekatan-pendekatan Pengembangan Kurikulum." QUDWATUNA 2.2 : 175-197.

[16] History Accessed from https://www.madania.sch.id/pages/history on July 24, 2021

[17] Karin, Nurul., \& Fakhruddin, Agus. "Pengembangan Kurikulum PAI di SMP Darul Hikam Internasional School dalam Rangka Penguatan Pendidikan Karakter". TARBAWY: Indonesian Journal of Islamic Education, 6(1), (2018). 80-89.

[18] Kemendikbud, Balitbang. Pendidikan di Indonesia Belajar dari Hasil PISA 2018. Jakarta: Pusat Penilaian Pendidikan Balitbang Kemendikbud. (2019).

[19] Luxon, Tony, and Moira Peelo. 2009. "Internationalisation: Its Implications for Curriculum Design and Course Development in UK Higher Education." Innovations in Education and Teaching International 46.1: 51-60.

[20] Madania as a Cambridge School. Accessed from https://www.madania.sch.id/pages/madania-asa-cambridge-school on July 24, 2021

[21] Mahsun, Ali. "Pendidikan Islam dalam Arus Globalisasi Sebuah Kajian Deskriptif Analisis". Jurnal Episteme, Vol. 8 No. 2, Desember. (2013).

[22] Manizar, E. “Optimalisasi Pendidikan Agama Islam di Sekolah”. Tadrib, 3(2), (2017). 251-278.

[23] Moeloeng, Lexy J. Metode Penelitian Kualitatif. Bandung: PT Remaja Rosdakarya. (2017.)

[24] Muhaimin. Paradigma Pendidikan Islam : Upaya Mengefektifkan Pendidikan Agama Islam di Sekolah. Bandung : PT. Remaja Rosdakarya. (2012).

[25] Muhaimin. Pengembangan Kurikulum Pendidikan Agama Islam di Sekolah, Madrasah dan Perguruan Tinggi. Jakarta : PT. RajaGrafindo Persada. (2012).

[26] Ng, Vinci. The Decision To Send Local Children To International Schools In Hong Kong: Local Parents' Perspectives. Asia Pacific Education Review, 13(1). Seoul: Education Research Institute, Seoul National University Korea. (2012). 121-136.

[27] Nichols, B., Shidaker, S., Johnson, G., Singer, K., \& Thomson, G. Managing Curriculum and Assessment: A Practitioner's Guide. Santa Barbara, Calif.: ABC-CLIO. (2006).

[28] Putra, A. A. "Konsep Pendidikan Agama Islam Perspektif Imam Al-Ghazali”. Jurnal Pendidikan Agama Islam Al-Thariqah, 1(1), (2016). 41-54.

[29] Qodir, Z. "Kaum Muda, Intoleransi, dan Radikalisme Agama". Jurnal Studi Pemuda, 5(1), (2016). 429-445.

[30] Razabiyah, N. Upaya Peningkatan Hasil Belajar Pendidikan Agama Islam Materi Iman Kepada Rasul-Rasul Allah Melalui Media Flip Chart dan Strategi Permainan Balon Not Pada Siswa Kelas VIII SMP Nusantara Desa Gedangan Kecamatan Tuntang Kabupaten Semarang Tahun Pelajaran 2019/2020. Doctoral Dissertation, IAIN SALATIGA.( 2019).

[31] Ruslan, Heri. Wow, Sekolah di Indonesia Ramai-ramai Terapkan Kurikulum Cambridge. Accesssed from https://www.republika.co.id/berita/mnuiii/wow-sekolah-di-indonesia-ramairamaiterapkan-kurikulum-cambridge on July 24, 2021 
[32] Saepudin, Juju "Pengembangan Kurikulum PAI di Sekolah Unggulan (Studi pada SMPN 2 Kota Bandar Lampung)”. Nur El-Islam, 1(2), (. 2014). 29-47.

[33] Sanjaya, Wina Kurikulum dan Pembelajaran Teori dan Praktik Pengembangan Kurikulum Tingkat Satuan Pendidikan (KTSP). Jakarta: Prenada Media Group. (. 2008).

[34] Sanjaya, Wina. Kurikulum dan Pembelajaran. Jakarta : Kencana. (2008).

[35] Santoso, A. R. "Pelaksanaan Fungsi Lembaga Pemberdayaan Masyarakat (LPM) dalam Pembangunan di Kelurahan Rawa Makmur Kecamatan Palaran Kota Samarinda". Ejournal Administrasi Negara Volume 4, Nomor 2, (2016) : 4013-4026

[36] Sarafianos, N., Giannakopoulos, T., Nikou, C., \& Kakadiaris, I. A. "Curriculum Learning Of Visual Attribute Clusters For Multi-Task Classification”. Pattern Recognition, 80, (2018). 94-108.

[37] Solikhin, A "Islam, Negara, dan Perlindungan Hak-Hak Islam Minoritas". Journal of Governance, 1(1). (2016).

[38] Suparman, D. T., \& PD, M. Kurikulum dan Pembelajaran. Grobogan: Penerbit CV. SARNU UNTUNG. (2014.)

[39] The Interview Report with Abdulloh, Islamic Religion Education Teacher of SMA Madania [40] The Interview Report with Adam Hermawan, Madania Curriculum Development and Quality Assurance (MCDQA) Team.

[41] The Interview Report with Ahmad Nurhidayat, Islamic Religion Education Teacher of SMA Madania

[42] The Interview Report with Alfi Afifah, The Head of Madania Curriculum Development and Quality Assurance (MCDQA).

[43] The Interview Report with Ninik Nimatur Rahmaniah, The Coordinator Islamic Religion Education Teacher of SMA Madania

[44] The Interview Report with Titin Indri Yastuti, Madania Curriculum Development, and Quality Assurance (MCDQA) Team.

[45] Usmar, A. "Model-Model Pengembangan Kurikulum dalam Proses Kegiatan Belajar". Jurnal An-Nahdhah, 11(2). (2017).

[46] Wekke, Ismail Suardi. "Pengembangan kurikulum pendidikan agama Islam muslim minoritas: pesantren Nurul Yaqin Papua Barat." Madrasah: Jurnal Pendidikan. (2013).

[47] Widyastono, Herry. "Pengembangan Kurikulum Sekolah Bertaraf Internasional". Jurnal Pendidikan dan Kebudayaan, 16(3), (2010. 265-274.

[48] Zais, R. S. Curriculum: Principles and Foundations. New York: Thomas. Y Crowell Company. (1976). 